\title{
Effects of Zinc Acetate on Thioacetamide-Induced Hepatotoxicity in Rats
}

\author{
Bastway, M.; Hasona N.A. and Abdel Hamid, H. \\ Department of Chemistry, Biochemistry Branch, Faculty of \\ Science, Beni-Suef University, Egypt
}

\begin{abstract}
The ameliorative activity of zinc acetate on thioacetamide-induced hepatotoxicity was studied in rats. Forty male rats were divided into four equal groups each of 10 . Two groups were controls, one treated with thioacetamide and one with only distilled water. Two groups received zinc acetate and intraperitoneal (IP) thioacetamide (400 $\mathrm{mg} / \mathrm{kg} \mathrm{b.wt.)} \mathrm{either} \mathrm{before} \mathrm{or} \mathrm{after} \mathrm{administration} \mathrm{of} \mathrm{zinc} \mathrm{acetate.} \mathrm{Liver} \mathrm{damage} \mathrm{was}$ assessed by estimation of plasma concentration of bilirubin and enzymes activities of aspartate aminotransferase, alanine aminotransferase, and hepatic glutathione, MDA levels; SOD and catalase activities. Treatment with zinc acetate signifcantly reduced thioacetamide-induced elevation in plasma bilirubin concentration and enzymes activities. It could be suggested that thioacetamide-induced liver damage in rats could be ameliorated by treatment with zinc acetate.
\end{abstract}

Key words: Hepatoprotective, Hepatotoxicity, Zinc acetate, Thioacetamide, [MDA] and $[S O D]$.

\section{INTRODUCTION}

Thioacetamide is a potent selective hepatotoxin, which has been widely used to induce acute and chronic liver injury ${ }^{(1)}$. Oxidative injury has been recognized as the major mechanism in thioacetamide induced liver damage, the oxidative metabolism of thioacetamide through the hepatic FAD monooxygenase system and cytochrome P-450 monooxygenase system produces reactive oxidative agents especially the very reactive compound. Thioacetamide-S-dioxide targets tissue macromolecules lipids, protein, and DNA- leading to tissue oxidative injury and necrosis It has been observed that thioacetamide causes tissue injury and necrosis/apoptosis through several processes related to lipid, protein and DNA peroxidation $^{(2)}$.

Zinc is an essential element for all living organism ${ }^{(3)}$. During the course of evolution, all organisms have taken up compound available from their environment and used for specific functions of their metabolism. Hence, organisms have developed a mechanism that allows them to regulate zinc uptake.

During the International Conference on Zinc and Human Health, (2000) held in Stockholm, researchers and nutritionists discussed the determination of zinc requirements, the assessment of zinc status at individual and population 
levels, and the risks linked to zinc deficiency.

The conclusions of the conference provided evidence of the importance of zinc in human health ${ }^{(4)}$. Zinc is essential for the normal growth and reproduction of all higher plants, animals, and humans, and it is therefore called a "micronutrient. Zinc has never been shown to interact directly with oxidant substances, but it exerts a protective antioxidant effect indirectly ${ }^{(5)}$.

Some possible antioxidant actions of zinc are (i)protective effect against vitamin E depletion, (ii) stabilization ofmembrane structure, (iii) limitation of endogenous free radical production, (iv) contribution to the structure of extracellular superoxide dismutase. Zinc plays an important role in protecting DNA from damage as a component of many DNA repair proteins $^{(\boldsymbol{6})}$.

\section{MATERIALS \& METHODS}

White male albino rats (Rattus norvegicus) weighing about $200 \pm 40$ g. were used as experimental animals in the present investigation. They were obtained from the animal house of Research Institute of Ophthalmology, El-Giza, Egypt and were kept under observation for about 15 days before the onset of the experiment to exclude any intercurrent infection. The chosen animals were housed in stainless steel cages at normal atmospheric temperature $(25 \pm$ $5^{\circ} \mathrm{C}$ ) and had a $12 \mathrm{~h} \mathrm{light} \mathrm{-} \mathrm{dark} \mathrm{cycle}$ (light on at $6.00-18.00 h$ ). Food and water were consumed ad libitum.
Thioacetamide:

Thioacetamide was used as an inducer for liver cirrhosis. It was purchased from Sigma company (United Kingdom).

Induction of liver cirrhosis by thioacetamide:

A single injection $(400 \mathrm{mg} / \mathrm{kg}$ b.wt. of TAA, dissolved in normal saline) was given intraperitoneally.

Zinc acetate and its dose:

Zinc acetate was purchased from Sigma company (United Kingdom).

\section{Zinc acetate dose:}

$10 \mathrm{mg} \mathrm{Zn/kg} \mathrm{body} \mathrm{weight} \mathrm{of} \mathrm{zinc}$ acetate given by oral gaveage daily for all experimental period ${ }^{(7)}$.

Animal grouping

Group I $(\mathbf{n = 1 0 )}$ normal control group was given distilled water orally and daily administered for 4 weeks.

Group II $(\boldsymbol{n}=\mathbf{1 0})$ TAA induced control group was given thioacetamide intraperitoneally injection $400 \mathrm{mg} / \mathrm{kg}$ b.wt. of rat.

Group III $(n=10)$ rats given intraperitoneally injection of thioacetamide $400 \mathrm{mg} / \mathrm{kg}$ b.wt. of rat then given by oral gaveage $10 \mathrm{mg} / \mathrm{kg}$ b.wt. of rat of zinc acetate for 4 weeks.

Group IV $(\boldsymbol{n}=\mathbf{1 0})$ rats given orally zinc acetate $10 \mathrm{mg} / \mathrm{kg}$ b.wt. of rats for one week then given intraperitoneally injection then complete oral gaveage zinc acetate $10 \mathrm{mg} / \mathrm{kg}$ b.wt. of rat for 4 weeks

\section{Biochemical Investigations:}

By the end of the experimental periods (4 weeks), rats were scarified under diethyl ether anesthesia at fasting state. The portion of blood samples were collected and allowed to coagulate at room temperature; other portion of blood added to it, EDTA 
(ethylene diamine tetracetic acid) and centrifuged at 3000 r.p.m. for 30 minutes. The clear, non-haemolysed supernatant sera and plasma were quickly removed divided into four portions for each individual, and stored at $-20^{\circ} \mathrm{C}$ for subsequent analysis.

Serum ALT and AST activities in serum was determined according to the method of Reitman and Frankel ${ }^{(\mathbf{8})}$ using reagent kits purchased from BioMerieux Chemical Company (France). Plasma total bilirubin and direct bilirubin concentrations were determined according to the method of Jendrassik ${ }^{(9)}$ using the reagent kits purchased from Diamond Diagnostics (Egypt). The content of reduced GSH was determined by modifying the method of Jollow et al. ${ }^{(10)}$. SOD activity was assayed as described by Kar and Mishra(11). Catalase activity was assayed as described by Choen $e t$ $a .^{(12)}$. A modification of the thiobarituric acid method was employed for the estimation of malondialdehyde according to Wright et al. ${ }^{(13)}$. Brifely, after incubation for
$60 \mathrm{~min}$ at $37^{\circ} \mathrm{c}$, a $1.0 \mathrm{ml}$ aliquot of the liver homogenate was mixed with 1.0 $\mathrm{ml} 40 \%$ trichloroacetic acid (TCA), followed by addition of $1.0 \mathrm{ml}$ $2 \%$ thiobarbituric acid. The mixture was boiled for $15 \mathrm{~min}$,cooled in an ice bath for $5 \mathrm{~min}$, and than $1 \mathrm{ml}$ $40 \%$ TCA was added to it .After standing for $20 \mathrm{~min}$, the mixture was centrifuged at $800 \mathrm{~g}$. for $20 \mathrm{~min}$, and the absorbence of the supernatant read at $532 \mathrm{~nm}$.

\section{Statistical analysis:}

Statistical analysis was done using the Statistical Package for the Social Sciences (SPSS for WINDOWS, version 11.0; SPSS Inc, Chicago).

Comparative analyses were conducted by using the general linear models procedure (SPSS Inc). Values of $\quad \mathrm{P}>0.05$ were considered statistically insignificant, while values of $\quad \mathrm{P}<0.05$ were considered statistically significant, values of $\mathrm{P}<0.01$ were considered statistically highly significant and $\mathrm{P}<0.001$ were considered statistically very highly significant.

\section{RESULTS}

Table(1): Effect of zinc acetate on serum activities of ALT and AST of TAA induced cirrhotic rats:

\begin{tabular}{lll}
\hline Groups & Serum ALT activity(u/l) & Serum AST activity(u/l) \\
\hline Group.(1) & $23.25 \pm 1.29$ & $39.81 \pm 2.36$ \\
\hline Group.(2) & $78.38 \pm 1.61+++$ & $117.73 \pm 5.06+++$ \\
\hline Group.(3) & $54.11 \pm 2.08^{* * *}$ & $66.47 \pm 2.66^{* * *}$ \\
\hline Group.(4) & $45.82 \pm 1.82^{* * *}$ & $55.72 \pm 1.52^{* * *}$ \\
\hline
\end{tabular}

Values significantly different compared to normal: $+++P<0.001$

Values significantly different compared to TAA. control: ***P $<0.001$ 
The cirrhotic rats exhibited a very highly significant increase $(\mathrm{P}<0.001)$ of serum ALT and AST activity as compared to the normal rats. The oral treatment of cirrhotic rats with zinc acetate exerted a very highly significant decrease $(\mathrm{P}<0.001)$ in serum ALT and AST activity as compared to the cirrhotic rats.

Table (2): Effect of zinc acetate on plasma levels of total bilirubin and direct bilirubin of TAA induced cirrhotic rats:

\begin{tabular}{|c|c|c|c|c|}
\hline Groups & $\begin{array}{l}\text { Plasma } \\
\text { bilirubin(mg/dl) }\end{array}$ & Total & $\begin{array}{l}\text { Plasma } \\
\text { bilirubin(mg/dl) }\end{array}$ & Direct \\
\hline Group.(1) & $0.57 \pm 0.05$ & & $0.31 \pm 0.04$ & \\
\hline Group.(2) & $4.49 \pm 0.17+++$ & & $2.53 \pm 0.14+++$ & \\
\hline Group.(3) & $2.35 \pm 0.16^{* * *}$ & & $31.44 \pm 0.14 * * *$ & \\
\hline Group.(4) & $1.36 \pm 0.08 * * *$ & & $0.77 \pm 0.06^{* * *}$ & \\
\hline
\end{tabular}

The TAA. induced rats showed a very highly significant increase in plasma bilirubin level as compared to normal control rat group. The oral treatment of cirrhotic rats with zinc acetate exerted a very highly significant decrease $(\mathrm{P}<0.001)$ in plasma bilirubin as compared to the cirrhotic rats.

Table (3): Effect of zinc acetate on hepatic levels of GSH and MDA of TAA induced cirrhotic rats:

\begin{tabular}{lll}
\hline Groups & $\begin{array}{l}\text { Groups Hepatic } \\
\text { GSH level(p mol/g Liver) }\end{array}$ & $\begin{array}{l}\text { Hepatic MDA level } \\
\text { (u mol/g Liver) }\end{array}$ \\
\hline Group.(1) & $39.93 \pm 1.35$ & $113.48 \pm 3.62$ \\
\hline Group.(2) & $12.51 \pm 0.77+++$ & $200.59 \pm 4.12+++$ \\
\hline Group.(3) & $19.63 \pm 0.62^{* * *}$ & $167.59 \pm 2.84 * * *$ \\
\hline Group.(4) & $26.39 \pm 1.40^{* * *}$ & $148.32 \pm 3.27 * * *$ \\
\hline Values significantly different compared to normal: $+++P<0.001$ \\
Values significantly different compared to TAA. control: $* * * P<0.001$
\end{tabular}


The cirrhotic rats exhibited a very highly significant decrease $(\mathrm{P}<0.001)$ of hepatic GSH level as compared to the normal rats. The oral treatment of cirrhotic rats with zinc acetate to TAA. induction exerted a very highly significant $(\mathrm{P}<0.001) \quad$ increase as compared to cirrhotic control group.
On the other hand, the hepatic MDA level showed a very highly significant increase $(\mathrm{P}<0.001)$ as compared to the normal rats. The oral administration of zinc acetate produced marked improvement $(\mathrm{P}<$ $0.001)$ of the altered hepatic MDA level of the cirrhotic rats.

Table (4): Effect of zinc acetate on hepatic activities of catalase and SOD of TAA induced cirrhotic rats:

\begin{tabular}{lll}
\hline Groups & $\begin{array}{l}\text { Hepatic Catalase } \\
\text { Activity(u/mg/protein/gm } \\
\text { tissue liver) }\end{array}$ & $\begin{array}{l}\text { Hepatic SOD } \\
\text { Activity(u/mg/protein/gm } \\
\text { tissue liver) }\end{array}$ \\
\hline Group.(1) & $138.99 \pm 5.64$ & $31.95 \pm 1.85$ \\
\hline Group.(2) & $54.82 \pm 3.22+++$ & $11.25 \pm 0.85+++$ \\
\hline Group.(3) & $65.41 \pm 1.69^{*}$ & $12.43 \pm 0.58$ \\
\hline Group.(4) & $84.24 \pm 2.65^{* * *}$ & $14.04 \pm 0.49^{* *}$ \\
\hline $\begin{array}{l}\text { Values significantly different compared to normal: }+++P<0.001 \\
\text { Values significantly different compared to TAA. control: } * P<0.05, * * P<0.01 \text { and } \\
* * * P<0.001\end{array}$
\end{tabular}

The cirrhotic rats exhibited a very highly significant decrease $(\mathrm{P}<0.001)$ of hepatic catalase activity as compared to the normal rats. The oral treatment of cirrhotic rats with zinc acetate exerted a significant increase $(\mathrm{P}<0.05)$ in hepatic catalase activity as compared to the cirrhotic rats. While, the protective groups showed a highly significant $\quad(\mathrm{P}<0.01) \quad$ increase as compared to cirrhotic control group.Olso, the hepatic SOD activity showed a very highly significant decrease $(\mathrm{P}<0.001)$ as compared to the normal rats. The oral administration of zinc acetate produced improvement of the altered hepatic SOD activity of the cirrhotic rats.

\section{DISCUSSION}

Oxidative stress has been implicated in liver cirrhosis. Carbon tetrachloride and thioacetamide are the most widely used models to develop cirrhosis in rats ${ }^{(14)}$.

The reactive oxygen species from thioacetamide (TAA) induces rat liver cirrhosis that resembles the human disease, and it can serve as a suitable 
animal model for studying human liver cirrhosis $^{(\mathbf{1 5})}$.

TAA is a hepatotoxin frequently used to induce hepatocellular injury and hepatic fibrosis in rats ${ }^{(\mathbf{1 6})}$. Its longterm administration causes the development of cirrhosis associated with an increased extent of lipid peroxidation $^{(\mathbf{1 7 )}}$.

Glutathione is an important endogenous antioxidant system that is found in particularly high concentration in liver and it is known to have key functions in protective processes. The reduced form of Glutathione (GSH) becomes readily oxidized to GSSG on interacting with free radicals. Excessive production of free radicals resulted in the oxidative stress, which leads to damage of macromolecules e.g. lipids, and can induce lipid peroxidation in-vivo ${ }^{(\mathbf{1 8})}$. Glutathione plays a major role as a reductant in oxidation-reduction processes and also serves in detoxification $^{(\mathbf{1 9 )}}$.

Our results are in agreement with Isaac Tunez et al. ${ }^{\mathbf{( 2 0 )}}$, TAA caused significant increases in the activities of aspartate. aminotransferase (AST) and alanine aminotransferase (ALT) in serum.

TAA also increased lipid peroxidation product levels, but reduced GSH content and catalase activity in the liver homogenate.

GSH plays an important role in hepatic antioxidation and drug metabolism. High intracellular GSH levels reduce damage and promote better survival under conditions of oxidative stress $^{(\mathbf{2 1})}$. Reduced glutathione (GSH) constitutes the first line of defense against free radicals. MDA level is a main marker of endogenous lipid peroxidation ${ }^{(22)}$. In the present study, TAA caused a highly significant increase in the level of hepatic MDA as compared to control one this finding was in agreement with the results of

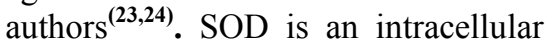
antioxidant enzyme that protect against oxidative process ${ }^{(\mathbf{2 5})}$.

The treatment of control group with thioacetamide showed a significant decrease in the activities of hepatic catalase and SOD as compared to normal group.

On the other hand, the treatment of TAA treated groups with zinc acetate showed marked ameliorations of transaminase enzymes activity (ALT and AST). These results are in accordance with the results of other authors $^{\mathbf{( 2 6 , 2 7 )}}$ whom showed the influence of zinc sulfate intake on acute ethanol-induced liver injury in rats.

The treatment with zinc acetate reversed the hyperbililirubinemia effect of thioacetamide on albino rats.

The role of $\mathrm{Zn}$ in the protection from free radical damage may take several forms, through maintaining an adequate level of metallothionein, an essential component of $\mathrm{Cu}, \mathrm{Zn}-\mathrm{SOD}$, a protective agent for thiols and other chemical groups ${ }^{(28)}$, that appear in the reduction of MDA level and increase in the activities of catalase and SOD after treatment with zinc acetate.

In conclusion, biochemical evaluations revealed that zinc acetate has a protective effect on thioacetamide induced liver injury. In such results zinc could acts as an antioxidant agent in hepatic antioxidant systems after thioacetamide administration. In 
addition, Zinc may be a therapeutic agent in the prevention and treatment of thioacetamide induced liver injury.

\section{REFERENCES}

1. Bruck R, Shirin H, Aeed H, Matas Z, Hochman A, Pines M, Avni Y. (2001): Prevention of hepatic cirrhosis in rats by hydroxyl radical scavengers. $J$ Hepatol., 35: 457-464.

2. Balkan J, Dogru-Abbasoglu S, Kanbagli O, Cevikbas U, Aykac-Toker G, Uysal M. (2001): Taurine has a protective effect against thioacetamideinduced liver cirrhosis by decreasing oxidative stress. Hum Exp Toxicol., 20(5):251-4.

3. Van Assche $F$, Martin $M$ (2002): Zinc in the environment Brussels: IZA International Zinc Association.

4. Zinc and Human Health (2000): Conclusions of the international Conference.

5. Di Silvestro RA. (2000): Zinc in relation to diabetes and oxidative disease. J Nutr., 130:1509-11.

6. Ho E. (2004): Zinc deficiency, DNA damage and cancer risk. J Nutr Biochem., 136: 193-8.

7. Ademuyiwa O, Onitilo O, Dosumu O, Ayannuga $\mathbf{O}$, Bakare A, Akinlatun W, Ogunyemi EO.(2002): Zinc in CCl4 toxicity. Biomed Environ Sci., 15(3):187-95.

8. Reitman,S. and Frankel, S.(1957): The colorimetric method for determination of serum gluytamic oxaloacetic transaminase and serum glutamic pyruvic transaminase. A. J. Clin. Pathol., 28:56.

9. Jendrassik L. (1938): Biochem. 81:7297.

10. Jollow D.J., Mitchell J.R., Zampaglione $N$. and Gillette J.R. (1974): Bromobenzene induced liver necrosis: protective role of glutathione and evidence for 3,4-bromobezene oxide as the hepatotoxic metabolite, Pharmacology., 11:151.

11. Kar M, Mishra D.1976: Catalase, Peroxidase, and Polyphenoloxidase Activities during Rice Leaf Senescence. Plant Physiol., 57(2):315-319.

12. Choen, G.; Dembiec, D. and Marcus, J (1970): Measurement of catalase activity in tissue. Analytical biochemistry., (34): 30-38.

13. Wright J.R., Colby H.D. and Miles P.R.(1981):, Cytosolic factors which affect microsomal lipid peroxidation in lung and liver, Archives of Biochemistry and Biophysics., 206: 296-304.

14. Natarajan SK, Thomas S, Ramamoorthy $\mathbf{P}$, Basivireddy $\mathbf{J}$, Pulimood AB, Ramachandran A, Balasubramanian KA (2006): Oxidative stress in the development of liver cirrhosis: a comparison of two different experimental models. J Gastroenterol Hepatol. Jun; 21(6):947-57.

15. An JH, Seong J, Oh H, Kim W, Han KH and Paik YH (2006): Protein expression profiles in a rat cirrhotic model induced by thioacetamide. Korean J Hepatol., Mar; 12(1):93-102. 
16. Muller A., F. Machnik, T. Zimmermann and $H$. Schubert (1988): Thioacetamide-induced cirrhosis-like liver lesions in ratsusefulness and reliability of this animal model, Experimental Pathology., 34:236.

17. Muller D., Sommer M., Kretzchmar M., Zimmerman T., Buko V.U., Lukivskaya O. and Dargel R.,(1991): Lipid peroxidation in thioacetamideinduced macronodular rat liver cirrhosis, Archives of Toxicology $65: 199-203$

18. Sinclair A.J., Barnett A.H. and Lunie J. (1991): Free radical and autooxidant systems in health and disease. Journal of Applied Medicine., 17 : 409.

19. Smith CV, Jones DP, Guenthner TM, Lash LH, Lauterburg BH. (1996): Compartmentation of glutathione: implications for the study of toxicity and disease. Toxicol Appl Pharmacol., 140:1-12.

20. Isaac Túnez, M. Carmen Muñoz, Michelle A. Villavicencio, Francisco J. Medina, Estíbaliz Pérez de Prado, Isabel Espejo, Montserrat Barcos, Manuel Salcedo, Montserrat Feijóo and Pedro Montilla (2005): Hepatoand neurotoxicity induced by thioacetamide: Protective effects of melatonin and dimethylsulfoxide. Pharmacological Research. 52(3): 223228.

21. Dickinson DA, Moellering DR, Iles KE, Patel RP, Levonen AL, Wigley A, Darley-Usmar VM, Forman HJ. (2003):
Cytoprotection against oxidative stress and the regulation of glutathione synthesis. Biol Chem., 384:527-37.

22. Deepa PR, Varalakshmi $\mathbf{P}(\mathbf{2 0 0 3 )}$ : Protective effect of low molecular weight heparin on oxidative injury and cellular abnormalities in adriamycininduced cardiac and hepatic toxicity. Clin Biochem., 146:201210.

23. Sehrawat A., Khan T.H., Prasad L. and Sultana S. (2006): Butea monosperma and chemomodulation: Protective role against thioacetamide-mediated hepatic alterations in Wistar rats. Phytomedicine 13: 157-163.

24. Edmund C. So; Kar-Lok Wong; Tian-Chyuan Huang; Sheng-Chou Tasi and Chi-Feng Liu (2002): Tetramethylpyrazine Protects Mice against Thioacetamide-Induced Acute Hepatotoxicity. J Biomed Sci., 9:410-414.

25. Bhatia S, Shukla R, Madhu SV, Gambhir JK, Prabhu KM (2003): Antioxidant status, lipid peroxidation and nitric oxide end products in patients of type- 2 diabetes mellitus with nephropathy. Clin Biochem., 36: 557-562.

26. Dashti HM, Mathew TC, Jadaon MM, Ashkanani E (1997): Zinc and liver cirrhosis: biochemical and histopathologic assessment. Nutrition., 13(3): 206-12.

27. Bolkent S., Pelin Arda-Pirincci, Sehnaz Bolkent, Refi ye Yanardag, Sevim Tunali, Sukriye Yildirim (2006): 
Influence of zinc sulfate intake on acute ethanol-induced liver injury in rats. World J Gastroenterol., 12(27): 4345-4351.

28. Yamaguchi, T., Sano, K., Takakura, K., Saito, I.,
Shinohara, Y., Asano, T. and Yasuhara, H. (1998): Ebselen in acute ischemic stroke: a placebocontrolled, double-blind clinical trial. Ebselen Study Group. Stroke 29, 12-17. 


\section{تأثير خلات الزنك على الجرذان المسممة بمادة الثيواسيتاميد}

$$
\begin{aligned}
& \text { محمد بسطاوي أحمد، نبيل عبد السلام حسونة، حنان عبد الحمبي سلبيان }
\end{aligned}
$$

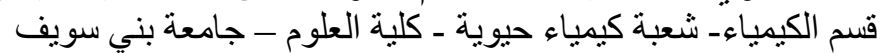

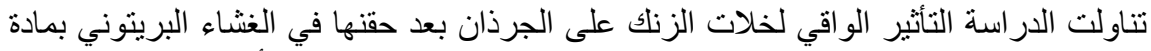

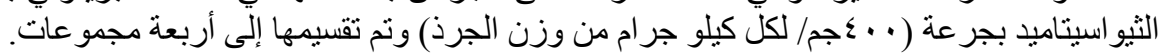

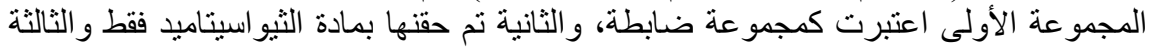

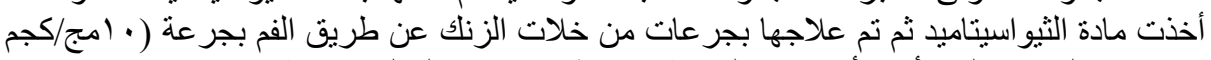

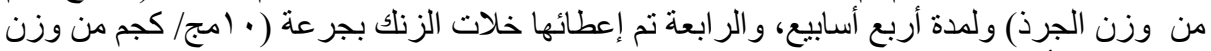

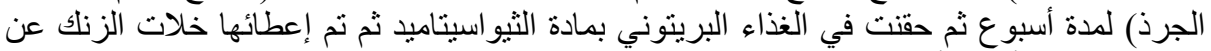
طريق الفم لمدة أربعة أسابيع بعد الثئ اسيتاميد. بعد انتهاء فترة المعالجة تم أخذ العينات من الدم و الكبد وتم قياس بعض القياسات الحيوية لوظائف

لوحظ من النتائج أن مادة خلات الزناك لها دور لئا هام في في حماية الكبد من التأثيرات السمية لمادة الثيو اسيتاميد التي تنتج شو ارد حرة لها نأثير ضار لكار على الكبد. 